THE FACES OF JUSTICE AND STATE AUTHORITY 
This page intentionally left blank 


\section{THE FACES OF}

\section{JUSTICE AND STATE AUTHORITY}

A Comparative Approach to the Legal Process

Mirjan R. Damaška

Yale University Press New Haven and London 
Copyright (C) 1986 by Yale University.

All rights reserved.

This book may not be reproduced, in whole or in part, in any form (beyond that copying permitted by Sections 107 and 108 of the U.S. Copyright Law and except by reviewers for the public press), without written permission from the publishers.

Designed by James J. Johnson

and set in Aldus and Palatino

Printed in the United States of America.

Library of Congress Cataloging-in-Publication Data

Damaška, Mirjan R., 1931-

The faces of justice and state authority.

Includes index.

1. Justice, Administration of. 2. Courts.

3. Law and politics. I. Title.

$\begin{array}{lll}\text { K2100.D36 } & 1986 \quad 347 & 86-7729 \\ \text { ISBN } 0-300-03567-5 \text { (dloth) } & 342.7 \\ \text { 0-300-05119-0 (pbk.) } & \end{array}$

The paper in this book meets the guidelines for permanence and durability of the Committee on Production Guidelines for Book Longevity of the Council on Library Resources.

$\begin{array}{lllllllll}10 & 9 & 8 & 7 & 6 & 5 & 4 & 3 & 2\end{array}$ 


\section{To My Parents}

toplini starog doma 
This page intentionally left blank 